\title{
USE OF ATMOSPHERIC PLASMA IN GERMINATION OF Hybanthus calceolaria (L.) Schulze-Menz SEEDS ${ }^{1}$
}

\author{
DINNARA LAYZA SOUZA DA SILVA ${ }^{2 *}$, MIKELLY DE LIMA FARIAS ${ }^{3}$, JUSSIER DE OLIVEIRA VITORIANO ${ }^{4}$, \\ CLODOMIRO ALVES JÚNIOR ${ }^{2}$, SALVADOR BARROS TORRES ${ }^{5}$
}

\begin{abstract}
Plasma technology is a fast, cost-effective, and pollution-free method that can be used in place of conventional methods to overcome seed dormancy. The goal of the present study was to determine the effect of different application times of atmospheric plasma on soaking and germination of Hybanthus calceolaria seeds in order to accelerate these processes. Helium plasma jet produced by dielectric barrier discharge was used to treat $H$. calceolaria seeds with applications of 1, 5, and 10 minutes. The treated seeds were characterized considering their weight variation during soaking, changes in electrical conductivity, and $\mathrm{pH}$. It was found that germination depended on the plasma application time. The treatment of $H$. calceolaria seeds with atmospheric plasma for 1 minute provided 3.5 times greater germination in comparison to untreated seeds. Atmospheric plasma technology obtained by dielectric barrier discharge had potential of being used as a germination accelerant in $H$. calceolaria seeds. The treatment of $H$. calceolaria seeds using atmospheric plasma for 1 minute favored germination.
\end{abstract}

Keywords: Germination accelerator. Cold plasma. Soaking. Surface treatment.

\section{USO DE PLASMA ATMOSFÉRICO NA GERMINAÇÃO DE SEMENTES DE Hybanthus calceolaria} (L.) Schulze-Menz

RESUMO - A tecnologia de plasma constitui-se em um método rápido, econômico e livre de poluição que pode ser utilizada na superação de dormência de sementes em substituição aos métodos convencionais. $\mathrm{O}$ objetivo com esse estudo foi verificar o efeito do tempo de aplicação de plasma atmosférico sobre a embebição e germinação de sementes de Hybanthus calceolaria visando à aceleração destes processos. Jato de plasma de gás hélio, produzido por descarga em barreira dielétrica (DBD), foi utilizado para tratar as sementes de $H$. calceolaria por 1, 5 e 10 minutos de aplicação. As sementes tratadas foram caracterizadas quanto à variação de peso durante a embebição, variações da condutividade elétrica e $\mathrm{pH}$. Verificou-se que a germinação depende do tempo de aplicação do plasma. O tratamento de sementes de $H$. calceolaria com plasma atmosférico por 1 min. proporcionou incremento na germinação de 3,5 vezes em comparação com as não tratadas. A tecnologia de plasma atmosférico, obtido por barreira dielétrica, apresenta potencial de utilização como acelerador da germinação de sementes de $H$. calceolaria. O tratamento de sementes de $H$. calceolaria à plasma atmosférico durante 1 minuto favorece a germinação.

Palavras-chave: Acelerador de germinação. Plasma frio. Embebição. Tratamento de superfícies. 


\section{INTRODUCTION}

Hybanthus calceolaria (L.) Schulze-Menz, species of the family Violaceae, has been widely used in the pharmacological and agrochemical sectors due to its high concentrations of cyclotides and proteins that originally compose the defense system of the plant (CHEN; CHEN; CHANG, 2012). These proteins have extensive biological activity, including the cytotoxic protein, which is recognized as a potent anticancer, insecticide, and antimicrobial agent (JENNINGS et al., 2005). In recent years, there has been a renewed interest in natural medicines obtained from parts of plants or their extracts.

In Western countries, the use of drugs totally or partially derived from natural sources has approximately reached $40 \%$ (ROUTA; SAMANTARAYB; DAS, 2000). In this sense, pharmaceutical companies largely rely on materials obtained from natural sources that are being rapidly depleted (GEORGE; SHERRINGTON, 1984). Regarding $H$. calceolaria, its habitat has being reduced due to its replacement with agricultural crops and, probably, due to the difficulty in germinating its seeds. Seed dormancy which is a characteristic of the family Violaceae (TRABI et al., 2004) is caused by the hydrophobicity of the integument, which becomes waterproof and restricts water absorption, thus making the process of seed germination difficult. In addition, this fact becomes an obstacle to large-scale cultivation.

Despite advances in pre-germination treatments, there are issues related to injuries in the seeds structure caused by scarification, which can reduce force, increase the rates of infections caused by microorganisms, increase the rate of abnormalities in plants, and compromise the development of the aerial part and phytomass production. In addition, the waste resulting from chemical treatments implies ecosystem damages (SELCUK; OKSUZ; BASARAN, 2008). These problems become more critical when they occur in large-scale production and reduced seed sizes, as is the case of $H$. calceolaria.

In view of the limitations of conventional methods used to overcome dormancy, there is a need to develop alternative technologies that allow the correlation between efficiency, sustainability, and financial viability. Cold plasma technology produced by dielectric barrier discharge (DBD) is a fast, cost-effective, and pollution-free method that can improve the germination performance of seeds and, consequently, the productivity of the crops (SELCUK; ORSUZ; BASARAN , 2008; SERÁ et al., 2008). In this sense, studies have been conducted with various species, such as: Oryza sativa (CHEN; CHEN; CHANG, 2012), Glycine max (LING et al., 2014), Leucaena leucocephala (GUIMARÃES et al., 2015) and Phaseolus vulgaris (BORMASHENKO et al., 2015).

The goal of the present study was to determine the effect of different application times of atmospheric plasma on soaking and germination of Hybanthus calceolaria seeds in order to accelerate these processes.

\section{MATERIAL AND METHODS}

The present study was conducted at the Federal Rural University of Semi-Árid, in the Seed Technology Laboratory and the Applied Plasma Laboratory, located in Mossoró, State of Rio Grande

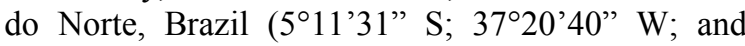
altitude of 16 meters).

The fruits of $H$. calceolaria were collected in Mossoró in 2012, and they were in early stages of maturation. After the harvest, the fruits were placed in covered containers until they opened completely. After the opening of the fruits, we performed manual processing and stored the seed in a cold chamber at $10{ }^{\circ} \mathrm{C}$, in the Seed Analysis Laboratory of the Federal Rural University of Semi-Árido in accordance with the method proposed by Pereira (2011)

The device used for obtaining the plasma jet consisted of a Petri dish, closed by two phenolite discs with $90 \mathrm{~cm}$ in diameter, and one side was coated with copper (Figure 1). The lower disc was grounded and the upper disc was used to close the Petri dish, which was cathodically polarized with $8.1 \mathrm{kV}$ voltage and frequency of $720 \mathrm{~Hz}$. The helium gas was introduced through an 8 -mm diameter hose that ended in the central hole of the upper disc and its flow rate was $2 \mathrm{~L} \mathrm{~min}^{-1}$.

The helium gas jet was ionized when passing through the upper electrode and spread inside the Petri dish due to the action of the anode placed at the base of the plate. The atmosphere formed by the application of plasma was characterized using an optical emission spectrometer (Ocean Optics USB4000) positioned on the side of the Petri dish. The energy per cycle and the dissipated power were determined using an oscilloscope, integrating voltage and current.

For the plasma treatment, we placed 200 seeds at a time without Petri disks taking up approximately $80 \%$ of the available area. The treatments were performed with duration of 1,5 , and 10 minutes. 


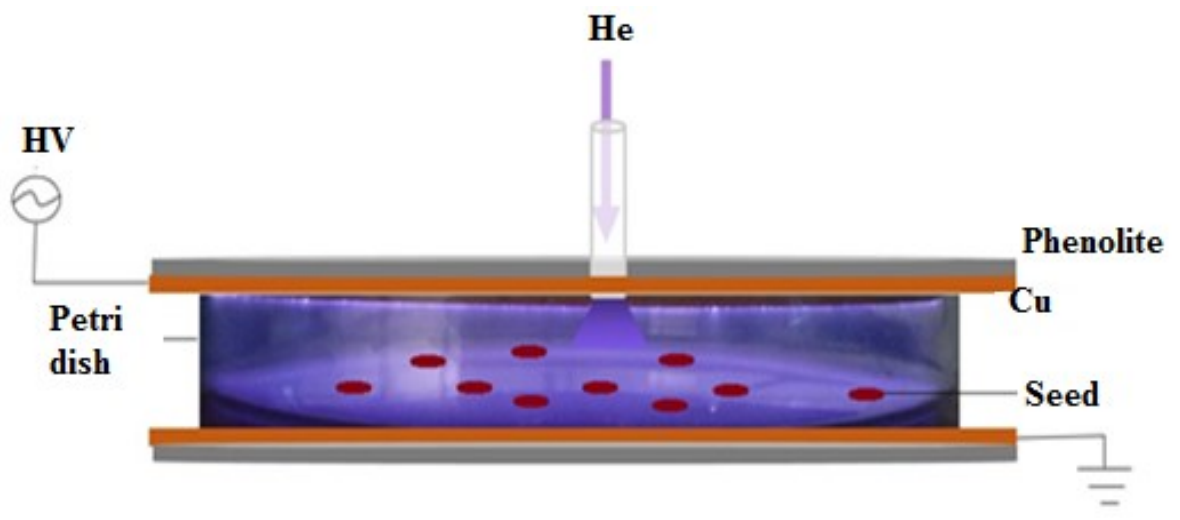

Figure 1. Diagram of the device used for obtaining cold plasma by dielectric barrier discharge for the treatment of Hybanthus calceolaria (L.) Schulze-Menz seeds.

For determining soaking, we used 200 seeds distributed in four replications of 50 seeds for each condition which, after treated by plasma, were placed in plastic cups containing $100 \mathrm{~mL}$ of distilled water.

The seeds were maintained at a temperature of $25{ }^{\circ} \mathrm{C}$, and the mass was determined at intervals of $4,10,24$ and 36 hours of soaking. Simultaneously, we measured the electrical conductivity and the $\mathrm{pH}$ of the solution. The variation in seed mass was determined by Equation 1.

$$
\% \text { Mass }=\frac{m_{f}-m_{i}}{m_{i}} \times 100
$$

Soaking is one of the germination stages, which includes the evaluation of dynamic water absorption by the seed. It is fundamental to understand the enzymatic activity and the degradation of reserve substances during this process.

The seeds were placed in polyethylene trays $(26 \times 18 \times 5.5 \mathrm{~cm})$ to germinate. For each treatment, we used 100 seeds with four repetitions of 25 , which were sown in sterile washed sand substrate.

The curve of cumulative germination was adjusted according to the model proposed by Richards (1959), which determines the population growth. The Richards's function (Yt) is represented by Equation 2 .

$$
Y_{t}=\frac{\alpha}{[1+b+d x \exp (-c x t)]^{1 / d}}
$$

In this case, functional parameters are associated with population parameters of the germination, such as: viability (Vi), which indicates the maximum germination of a seed lot; median $(\mathrm{Me})$, which indicates the time at which $50 \%$ of germination is achieved; dispersion $(\mathrm{Qu})$, which gives an indication of germination uniformity; and asymmetry (Sk), which represents the asymmetry of Richards's curve (1959) with respect to the inflection points.

The experimental design was completely randomized with four treatments $(0,1,5$, and 10 minutes of plasma application). The analysis of variance was performed using Tukey's test at 5\% and the SISVAR statistical program.

\section{RESULTS AND DISCUSSION}

The optical spectra of plasma were obtained by optical fiber, transmitted to the optical emission spectrometer for diagnosis of plasma species (Figure 2).

The peaks observed resulted from the excitement of the nitrogen molecules (N2) of the second positive system, N2 (C 3 Пu) $\rightarrow$ (B 3 Пg) with different energy levels. The most intense peaks occur at 337,357 , and $380 \mathrm{~nm}$, corresponding to transitions (v', v') of (0.0), (0.1), and (0.2), respectively (POIATA et al., 2010). This was the result of the collision at the exit of the tube between electrons present in the helium gas flow $(\mathrm{He})$ ionized with N2 molecules present in the air. We did not observe other species that could be present, as those derived from $\mathrm{He}$ and the oxygen molecules, which have emissions of wavelengths over $600 \mathrm{~nm}$. Nitrogen-containing plasma systems have been widely used due to their ability to introduce amine, imine, amide, nitrite, and other functionalities to increase the wettability of the polymer surface (AREFI-KHONSARI et al., 1998).

The description of the atmosphere formed from the plasma treatment (Figure 2) represents evidence for the functional groups present on the surface of the seeds that were able to modify the soaking process through increased wettability, as shown in Figure 3.

It was possible to observe the variation in wettability of seeds after the plasma treatment, in which treated seeds exhibited greater mass variation in comparison to untreated seeds (Figure 3). 


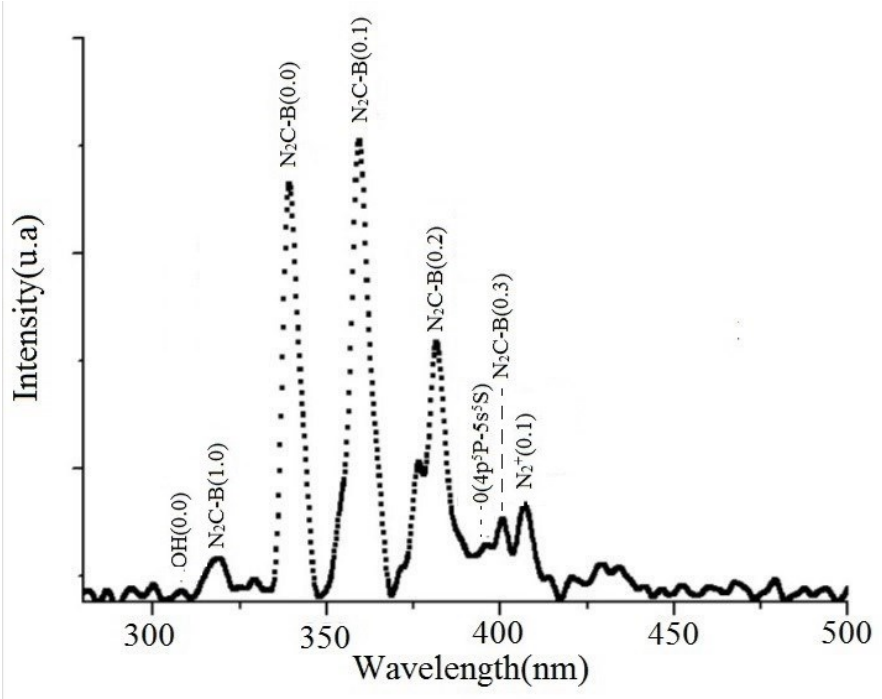

Figure 2. Spectrum plasma emission discharge between two glass tubes in the reactor.

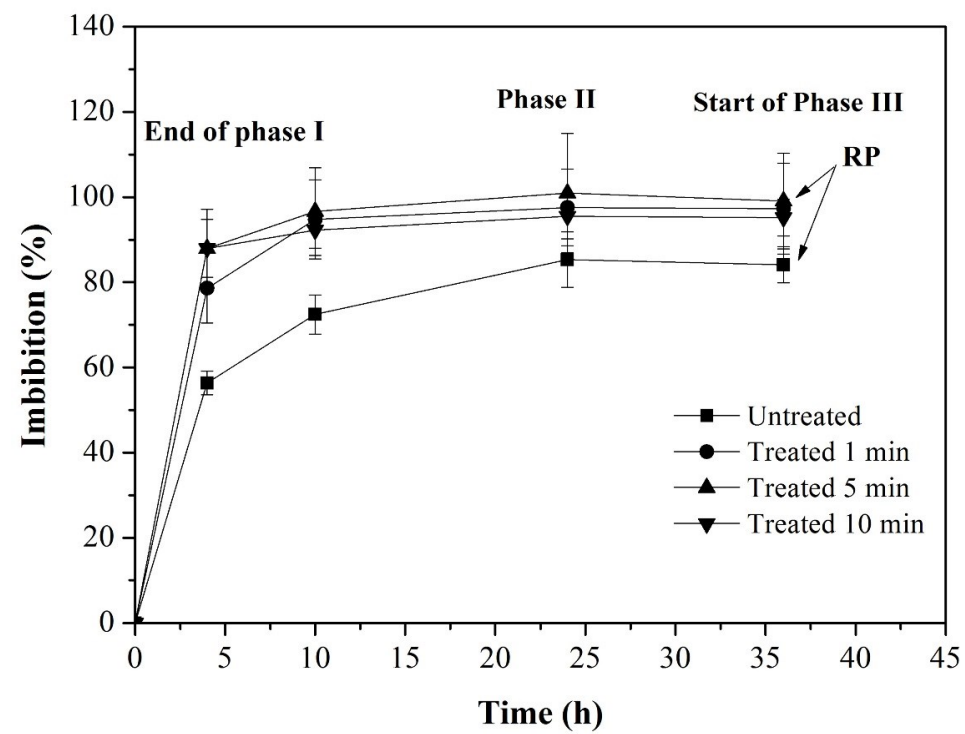

Figure 3. Soaking of Hybanthus calceolaria (L.) Schulze-Menz seeds.

The mass increase with the DBD plasma treatments of 1 and 5 minutes was $90 \%$, and the increase with the treatment of 10 minutes was $78 \%$. On the other hand, the increase in untreated seeds was $58 \%$ (Figure 3 ).

The results of the soaking curve (Figure 3) indicated that the $H$. calceolaria seeds featured a three-phase behavior. The first phase was characterized by intense and rapid water absorption (lasting up to 5 hours) in all conditions tested.

The abrupt gain of initial mass during phase 1 of soaking was controlled by matrix forces between the dry seeds and water content in the germination substrate. According to Stendahl (2005), this fact is common in several botanical species (RODRIGUES-JÚNIOR et al., 2014; JAYASURIYA et al., 2009).

Phase 2 (stationary phase) was characterized by intense metabolic activity with active transport of reserve substances (protein, carbohydrates, and lipids), in addition to the balance between the osmotic potential and pressure potential, which resulted in slow water absorption (BEWLEY; BLACK 1994).

In our experiment, the phase 2 of the soaking process lasted 36 hours when there was radicle emission. The treated seeds reached $98 \%$ of water content, whereas the untreated seeds reached $80 \%$.

In phase 3 , characterized by the growth of the radicle, the processes of cell division and elongation were observed 36 hours after the beginning of soaking. This result was the same in all the conditions tested.

We observed increase of $30 \%$ in the water absorption of the seeds during the soaking period after the plasma treatment (Figure 3). Plasma interacts on the surfaces of seeds and changes their structure chemically (STOFFELS; 
SAKIYAMA; GRAVES, 2008; LING et al., 2014; BORMASHENKO et al., 2015), through the adsorption of functional groups, such as $\mathrm{N} 2, \mathrm{~N} 2+, \mathrm{O}$, and 0.3 , providing hydrophilic characteristic to the integument and increasing water absorption. This fact was corroborated by the results obtained in the present study.

The assessment of the flow of substances and ions during germination is performed through the analysis of electrical conductivity and $\mathrm{pH}$, monitored during the soaking phases (Figure 3). Several studies have used the electrical conductivity and $\mathrm{pH}$ in combination with the germination test to assess the

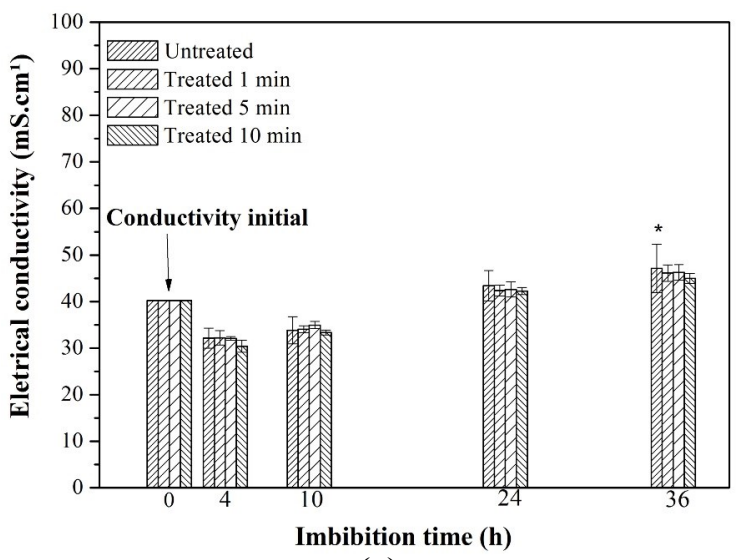

(a) physiological quality of seeds, due to the direct correlation of these tests with the germination vigor and rate (TAJBAKHSH, 2000). Still, according to the same author, the seeds with high physiological quality exhibit low leaching of solutes, whereas the less vigorous seeds release greater amount of ions and exhibit lower $\mathrm{pH}$ values.

Initially, we observed a reduction in electrical conductivity during the first four hours of soaking in all the experimental conditions (Figure 4a). This reduction probably occurred by the retention of $\mathrm{H}+$ ions and increased slightly acidic $\mathrm{pH}(\mathrm{pH}=6.5)$, during phase 1 of the soaking process (Figure $4 \mathrm{~b}$ ).

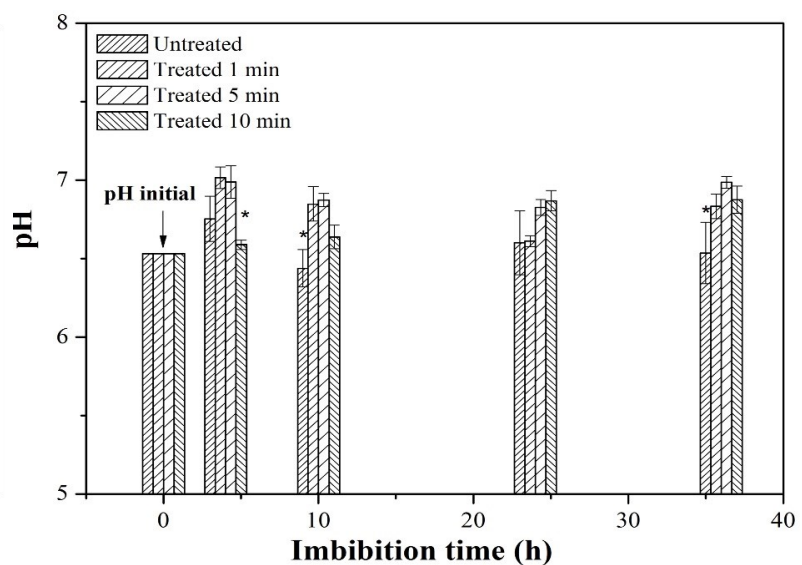

(b)

Figure 4. Behavior of electrical conductivity (a) and $\mathrm{pH}$ (b) of leached water during soaking of Hybanthus calceolaria (L.) Schulze-Menz seeds. The data points represent mean \pm standard deviation of four repetitions. $*$ Tukey's test $=p<0.05$.

We observed an increase in electrical conductivity between 10 and 36 hours of soaking, which may have indicated the occurrence of solutes leaching by the seeds. This fact occurs during germination, and substances such as: sugars, amino acids, fatty acids, enzymes, and inorganic ions $(\mathrm{K}+$, $\mathrm{Ca} 2+, \mathrm{Mg} 2+$, and $\mathrm{Na}+$ ) are transformed into energy to feed the embryo (AOSA, 2002).

The behavior of $\mathrm{pH}$ depends on $\mathrm{H}+$ and $\mathrm{OH}$ concentrations. In the present study, we observed an increase in $\mathrm{pH}$ between 4 and 36 hours of soaking in all the conditions analyzed; even though there were oscillations and the $\mathrm{pH}$ remained greater than its initial value (Figure 4b). The initial increase in $\mathrm{pH}$ can be explained by the reduction of $\mathrm{H}+$ in the solution. This fact was evidenced by the drop in electrical conductivity during the same period, which entailed the effective release of salts during the soaking process, as suggested by Tajbakhsh (2000).

With the DBD plasma treatment in the $H$. calceolaria seeds, the electrical conductivity was similar to that of untreated seeds. However, after soaking for 24 hours, the untreated seeds exhibited greater electrical conductivity than the treated seeds.
Regarding $\mathrm{pH}$, the treated seeds obtained greater values during 5 and 10 minutes with 20 hours of soaking. The amount of leached ions in the soaking solution indirectly reflected the cell membranes damage resulting from the process of seeds deterioration (AOSA, 2002).

Alves Júnior et al. (2016a) and Zhou et al. (2016) assessed the effects of atmospheric plasma treatment on seeds of Spondias tuberosa and Phaseolus vulgaris and observed changes in the physical and physiological responses of the seeds after treatment by DBD plasma. These results are in line with those obtained in the present study. This way, those authors indicated the atmospheric plasma technology as a promising method for overcoming seed dormancy, and affirmed that the popularization of this technique was possible.

The different germination behaviors of $\mathrm{H}$. calceolaria seeds observed in the present study, which depended on the time of DBD plasma treatment, are represented by the adjusted cumulative germination curves proposed by Richards (1959) (Figure 5). 
D. L. S. SILVA et al.

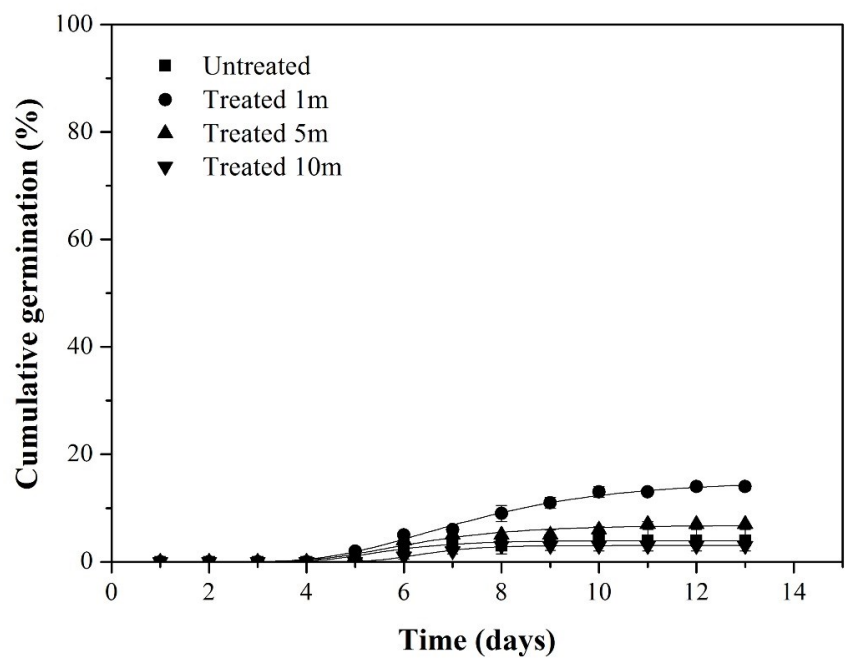

Figure 5. Cumulative germination of Hybanthus calceolaria (L.) Schulze-Menz seeds according to the application time of plasma obtained by dielectric barrier discharge.

The effects of plasma on the surface of seeds have been scientifically proven. These results are especially related to the induction of increased germination and growth of seedlings. These processes occur through the adsorption of the functional groups originated from the interaction between free radicals produced by plasma and the constituent elements of the integument. This way, there is increased absorption of water by the seeds (LING et al., 2014; BORMASHENKO et al., 2015;
ZAHORANOVA et al., 2016; ALVES JÚNIOR. et al., 2016b; SIVACHANDIRAN; KHACEF, 2017).

Population parameters obtained from Richards's adjustment, such as: viability (Vi); median (Me); dispersion (Qu); and asymmetry (Sk), provided all the information of the adjusted germination curve and described all the properties of germination, whose population parameters are illustrated in Table 1.

Table 1. Probability test between the population parameters of Hybanthus calceolaria (L.) Schulze-Menz seeds under different conditions of plasma treatment.

\begin{tabular}{llclll}
\hline & \multicolumn{5}{c}{ Plasma treatment $(\min )$} \\
\cline { 2 - 6 } $\mathrm{V}_{\mathrm{i}}(\%)$ & \multicolumn{1}{c}{0} & \multicolumn{1}{c}{5} & \multicolumn{1}{c}{10} & $P$ value \\
\cline { 2 - 6 } $\mathrm{M}_{\mathrm{e}}$ (days) & $4.0 \pm 0.2^{\mathrm{c}}$ & $14.0 \pm 0.8^{\mathrm{a}}$ & $7 \pm 0.5^{\mathrm{b}}$ & $3.0 \pm 0.1^{\mathrm{c}}$ & $0.02^{*}$ \\
$\mathrm{Q}_{\mathrm{u}}$ (days) & $5.6 \pm 0.6^{\mathrm{c}}$ & $7.3 \pm 0.5^{\mathrm{a}}$ & $3.3 \pm 0.9^{\mathrm{b}}$ & $0.7 \pm 0.2^{\mathrm{d}}$ & $0.03^{*}$ \\
$\mathrm{~S}_{\mathrm{k}}(\%)$ & $0.84 \pm 0.50^{\mathrm{c}}$ & $1.67 \pm 0.40^{\mathrm{a}}$ & $1.2 \pm 1.0^{\mathrm{b}}$ & $0.61 \pm 0.52^{\mathrm{c}}$ & $0.03^{*}$ \\
\hline
\end{tabular}

*Difference at $5 \%$ level according to Tukey's test.

The Vi values of the treatment with DBD plasma for 1 and 5 minutes indicated a significant germination increase $(p<0.05)$ in comparison to the values of untreated seeds. On the other hand, the treatment performed for 10 minutes reduced seed germination and the parameter $\mathrm{Vi}$ was similar to that of untreated seeds.

In general terms, the plasma treatment promoted significant increase in the germination process and became a viable alternative for largescale cultivation. In addition, the results indicated that there is an optimal time of plasma treatment for H. calceolaria.

The median value $(\mathrm{Me})$ allowed determining whether there were changes in the biological cycle of the species studied (SERÁ et al., 2009). According to the results obtained for the $\mathrm{Me}$ of $\mathrm{H}$. calceolaria seeds (Table 1), it is possible to suggest that the plasma treatment caused changes in the germination characteristics, modifying the biological cycle of the species studied $(p<0.05)$. This fact confirms the observations of Será et al. (2009), in which the germination speed was delayed as the treatment time was increased, resulting in decreased germination in times greater than 1 minute.

The dispersion parameter $(\mathrm{Qu})$, which indicates germination uniformity, showed differences $(\mathrm{p}<0.05)$ between treatments. Therefore, it is possible to assume that $\mathrm{H}$. calceolaria seeds submitted to plasma application had higher dispersion coefficients and generated germination mismatch. This fact was confirmed by the parameter Sk (asymmetry) which, according to Hara (2001), indicates the set of seeds with rapid germination. We observed that, under the conditions of plasma treatment, a small set of seeds achieved rapid 
germination.

\section{CONCLUSIONS}

A Atmospheric plasma technology obtained by dielectric barrier discharge has potential for being used as an accelerant of $H$. calceolaria seeds germination.

The treatment of $H$. calceolaria seeds using atmospheric plasma for 1 minute favors germination.

\section{REFERENCES}

ALVES JÚNIOR, C. et al. Dielectric-barrier discharge plasma effect on the physico-chemical properties of the seed coat and seed germination of umbu (Spondias tuberosa Arr Camara). Plasma Medicine, Danbury, v. 6, n. 3/4, p. 361-373, 2016 a.

ALVES JÚNIOR, C. et al. Water uptake mechanism and germination of Erythrina velutina seeds treated with atmospheric plasma. Scientific Reports, London, v. 3, n. 6, p. 3722-3726, 2016 b.

AREFI-KHONSARI, F. et al. Study of the surface properties and stability of polymer films treated by $\mathrm{NH}_{3}$ plasma and its mixtures. Journal Photopolym Science and Technology, Paris, v. 11, n. 2, p. 277292, 1998.

ASSOCIATION OF OFFICIAL SEED ANALYSTS - AOSA. Seed vigor testing handbook. East Lansig: AOSA, 2002. 105 p. (Contribution, 32).

BEWLEY, D.; BLACK, M. Seeds: physiology of development and germination. 2. ed. New York and London: Plenum Press, 1994. 445 p.

BORMASHENKO, E. et al. Interaction of cold radiofrequency plasma with seeds of beans (Phaseolus vulgaris). Journal of Experimental Botany, Ariel, v. 66, n. 13, p. 4013-4021, 2015.

CHEN, H. H.; CHEN, Y. K.; CHANG, H. C. Evaluation of physicochemical properties of plasma treated brown rice. Food Chemistry, Makung City, v. 135 , n. 1, p. 74-79, 2012.

GEORGE, E. F.; SHERrington, P. D. Plant propagation by tissue culture. Eversley: Exegetics Ltda., 1984. p. 39-71.

GUIMARÃES, I. P. et al. Double barrier dielectric plasma treatment of Leucaena seeds to improve wettability and overcome dormancy. Seed Science and Technology, Zurich, v. 43, n. 3, p. 526-530, 2015.
HARA, Y. Application of parametrization using the Richard's function to nitrogen release from coated urea and growth of ride seeds. Japan of Agricultural Research Quarterly, Tokyo, v. 35, n. 3 , p. 155-161, 2001 .

JAYASURIYA, K. M. G. G. et al. A proposed mechanism for physical dormancy break in seeds of Ipomoea lacunosa (Convolvulaceae). Annals of Botany, Lexington, v. 103, n. 3, p. 433-445, 2009.

JENNINGS, C. et al. Isolation, solution structure, and insecticidal activity of kalata B2, a circular protein with a twist: do möbius strips exist in nature? Biochemistry, Victoria, v. 44, n. 3, p. 851-860, 2005.

LING, L. et al. Effects of cold plasma treatment on seed germination and seedling growth of soybean. Scientific Reports, Nanjing, v. 4, n. 5859, p. 2045 2322, 2014.

PEREIRA, M. S. Manual técnico: conhecendo e produzindo sementes e mudas da Caatinga. 1. ed. Fortaleza, CE: Associação Caatinga, 2011.86 p.

POIATA, A. et al. Microorganism response to atmospheric pressure helium plasma DBD treatment. Journal of Electrostatics, Iasi, v. 68, n. 2, p. 128$131,2010$.

RICHARDS, F. J. A flexible growth function for empirical use. Journal of Experimental Botany, London, v. 10, n. 2, p. 290-300, 1959.

RODRIGUES-JÚNIOR, A. G. et al. Physical dormancy in Senna multijuga (Fabaceae: Caesalpinioideae) seeds: the role of seed structures in water uptake. Seed Science Research, Wallingford, v. 24, n. 2, p. 147-157, 2014.

ROUTA, G. R.; SAMANTARAYB, S.; DAS, P. In vitro manipulation and propagation of medicinal plants. Biotechnology Advances, Orissa, v. 18, n. 2, p. $91-120,2000$.

SELCUK, M.; OKSUZ, L.; BASARAN, P. Decontamination of grains and legumes infected with Aspergillus spp. and Penicillum spp. by cold plasma treatment. Bioresource Technology, Isparta, v. 99, n. 11, p. 5104-5109, 2008.

SERÁ, B. et al. Germination of Chenopodium Album in response to microwave plasma treatment. Plasma Science and Technology, Ceské Budejovice, v. 10, n. 4 , p. 506-511, 2008.

SERÁ, B. et al. Does cold plasma affect breaking dormancy and seed germination? A study on seeds of lamb's quarters (Chenopodium album agg.). 
Plasma Science and Technology, Ceské Budejovice, v. 11, n. 6, p. 750-754, 2009.

SIVACHANDIRAN, L.; KHACEF, A. Enhanced seed germination and plant growth by atmospheric pressure cold air plasma: combined effect of seed and water treatment. RSC Advances, Orléans, v. 7, n. 4, p. 1822-1832, 2017.

STENDAHL, F. Seed coating for delayed germination: a tool for relay cropping of annual crops. 6. ed. Uppsala: Swedish University of Agricultural Sciences, 2005. p. 65.

STOFFELS, E.; SAKIYAMA Y.; GRAVES, B. Cold atmospheric plasma: charged species and their interactions with cells and tissues. IEEE Transactions on Plasma Science, Chiang Mai, v. 36, n. 4, p. 1441-1451, 2008.

TAJBAKHSH, M. Relationships between electrical conductivity of imbibed seeds leachate and subsequent seedling growth (viability and vigour) in omid wheat. Journal of Agricultural Science and Technology, Urmia, v. 2, n. 1, p. 67-71, 2000.

TRABI, M. et al. Variations in cyclotide expression in Viola Species. Journal of Natural Product and Plant Resources, Brisbane, v. 67, n. 5, p. 806-810, 2004.

ZAHORANOVA, A. et al. Effect of cold atmospheric pressure plasma on the wheat seedlings vigor and on the inactivation of microorganisms on the seeds surface. Plasma Chemistry Plasma Process, Jiangsu, v. 36, n. 36, p. 397-414, 2016.

ZHOU, R. et al. Effects of atmospheric-pressure $\mathrm{N}_{2}$, $\mathrm{He}$, air, and $\mathrm{O}_{2}$ microplasmas on mung bean seed germination and seedling growth. Scientific Reports, Xiamen, v. 6, n. 3, p. 32603-32606, 2016. 